\title{
Emissions of Polychlorinated Dibenzo-p-dioxins and Dibenzofurans from Various Stationary Sources
}

\author{
Jen-Ho Kao ${ }^{1}$, Kang-Shin Chen ${ }^{1 *}$, Guo-Ping Chang-Chien ${ }^{2}$, I-Cheng Chou ${ }^{2}$ \\ ${ }^{1}$ Institute of Environmental Engineering, National Sun Yat-Sen University, Kaohsiung 804, \\ Taiwan \\ ${ }^{2}$ Department of Chemical and Material Engineering, Cheng Shiu University, Kaohsiung County \\ 833, Taiwan
}

\begin{abstract}
This work investigated the characteristics of polychlorinated dibenzo-p-dioxins and dibenzofurans $(\mathrm{PCDD} / \mathrm{F})$ in stack-flue gases from six stationary emission sources in five types of incinerators: industrial waste incinerator (IWI), small-scale municipal solid waste incinerator (MSWI), medical waste incinerator (MWI), cement kilns (CK), and crematories (CR). These characteristics were further investigated using factor analysis and cluster analysis. Experimental results reveal that PCDDs dominate MSWI and CR, and PCDFs dominate IWIa, IWIb, CK and MWIs. The factor analysis results showed that CR and MSWI have similar fingerprints, as do IWIb and MWI3. The cluster analysis showed that if a vertical line is cut at a rescaled distance of four, then the PCDD/F congener profiles fall into four groups. The indicators of PCDD/Fs are OCDD, 1,2,3,4,6,7,8-HpCDF, 2,3,4,7,8-PeCDF, and 1,2,3,4,6,7,8-HpCDD. The emission factors of PCDD/Fs herein were from 0.0433 (CK) to 18.7 (MSWI) $\mu \mathrm{g}$ I-TEQ/ton-feedstock.
\end{abstract}

Keywords: Dioxin emission, incinerators, congener profile, factor analysis, cluster analysis

\footnotetext{
* Corresponding author: Tel/Fax: +886-7-5254406

E-mail address: shin@mail.nsysu.edu.tw
} 


\section{INTRODUCTION}

Dioxins, especially 2,3,7,8-TCDD, are of great concern, because they are highly carcinogenic. $\mathrm{PCDD} / \mathrm{Fs}$ are formed during combustion from: (i) precursors, (ii) de novo, and (iii) through pyrosynthesis (Tuppurainen et al., 2003). Major sources of atmospheric PCDD/Fs include stationary emissions, especially from various incinerators, including secondary aluminum smelters (ALS), sinter plants, small-scale municipal solid-waste incinerators (MSWI), medicalwaste incinerators (MWI), electric-arc furnaces (EAF), industrial-waste incinerators (IWI), cement kilns and crematoria. Hence, this work studies PCDD/F emissions from MSWI, MSI, IWI, crematory cement kilns (CK), and cement crematoria (CR).

Cement kilns use coal as burner fuel; the other sources use diesel. The feedstock of $\mathrm{CK}$ is mostly cement as a raw material and a few waste tires, IWIa is fed with general waste from nuclear power plants, and IWIb is fed mostly with waste-oil sludge. For pollution control, MSWI uses a semi-dry washing tower and a baghouse, MWI uses a Venturi scrubber and a quench tower, CK uses an electrostatic precipitation (ESP), IWIa uses a baghouse, and IWIb uses a cyclone and an ESP.

This paper reports on measurements of PCDD/Fs from the stacks of six incinerators. Emission characteristics of PCDD/Fs from these incinerators are presented, including concentrations, fingerprints and emission factors. Also, similar and dissimilar features between them are further studied using factor analysis and cluster analysis. The data derived from this study can provide guidance to improve operating conditions of the incinerators and to assess the potential health risk to the neighboring community.

\section{EXPERIMENTAL}

\section{PCDD/FS Sampling}

PCDD/Fs in stack-flue gases were collected using the Taiwan EPA method NIEA A807.73C, which is based on the US EPA Method 23A. Prior to sampling, XAD-2 resin was spiked with isotopically labelled PCDD/F surrogate standards. Each stack gas sampling took $3 \mathrm{~h}$. One trip blank and one field blank were also obtained during field sampling to ensure that the collected samples were not contaminated.

\section{PCDD/FS Analysis}

PCDD/Fs were analyzed for stack-flue gases, according to U.S. EPA modified Method 23, using high-resolution gas chromatographs/high-resolution mass spectrometers (HRGC/HRMS). The analysis was conducted at the Super Micro Mass Research and Technology Center at Cheng Shiu University in Taiwan. The HRGC (Hewlett-Packard 6970) was comprised of a DB-5 MS 
fused silica capillary column $(0.25 \mathrm{~mm} \times 60 \mathrm{~m}, 0.25 \mu \mathrm{m})(\mathrm{J} \& \mathrm{~W}$ Scientific) with splitless injection. Helium was used as the carrier gas. The HRMS (Micormass Autospec Ultima, Manchester, UK) had a positive electron impact $(\mathrm{EI}+)$ source. The selected ion-monitoring mode (Park et al., 2004) had a resolving power of 100,000. The specified electron energy and source temperature were $35 \mathrm{eV}$ and $250{ }^{\circ} \mathrm{C}$, respectively.

\section{RESULTS AND DISCUSSION}

\section{PCDD/F Concentrations in Stacks}

Table 1 shows that the total PCDD/F concentrations in the stack gases of IWIa, IWIb, MSWI, MWI, CK, and CR were 0.604, 1.397, 30.1, 1.14, 0.350, and $29.8 \mathrm{ng} / \mathrm{Nm}^{3}$, respectively, and the order was MSWI $>\mathrm{CR}>\mathrm{IWIb}>\mathrm{MWI}>\mathrm{IWIa}>\mathrm{CK}$, indicating that $\mathrm{PCDD} / \mathrm{F}$ concentrations in the stacks of MSWI and CR greatly exceeded those of other incinerators. The efficiency of a baghouse in removing PCDD/Fs was around 37.6\% (Lee et al., 2004); so, highly concentrated PCDD/Fs could be formed from MSWI during combustion. CR should include pollution control equipment to reduce the concentration of $\mathrm{PCDD} / \mathrm{Fs}$ in the stack-flue gases. The PCDD to PCDF ratios were $0.464,0.415,0.903,0.423,0.292$, and 0.869 , respectively. The PCDD/Fs ratios in the stacks followed the order $\mathrm{CR}>\mathrm{MSWI}>\mathrm{IWIa}>\mathrm{MWI}>\mathrm{IWIb}>\mathrm{CK}$, indicating that PCDDs dominated CR and MSWI and PCDFs dominated the other burners. The total PCDD/Fs I-TEQs were $0.030,0.137,3.35,0.168,0.062$, and $3.00 \mathrm{ng} \mathrm{I-TEQ} / \mathrm{Nm}^{3}$, respectively. The order of total PCDD/F I-TEQ was MSWI $>$ CR $>$ MWI $>$ IWIb $>$ CK $>$ IWIa, similar to that of the total $\mathrm{PCDD} / \mathrm{F}$ concentration in stacks.

In summary, when considering PCDD/F concentrations, PCDD/F ratio and PCDD/F I-TEQ, MSWI and CR are two leading PCDD/F contributors among the six incinerators.

\section{PCDD/F Congener Profiles of Stationary Emission Sources}

Fig. 1 presents the congener profiles of the 17 2,3,7,8-chlorinated substituted $\mathrm{PCDD} / \mathrm{Fs}$ detected in six stack-flue gases. Each selected congener was normalized to the total weight of all 2,3,7,8-congeners (mean $\pm \mathrm{SD}$ ). The $\mathrm{PCDD} / \mathrm{F}$ congener profile of IWIa was dominated by $1,2,3,4,6,7,8-\mathrm{HpCDF}$, OCDD, and OCDF, while that of IWIb was dominated by $1,2,3,4,6,7,8-$ $\mathrm{HpCDF}$, OCDD, and 2,3,4,7,8-PeCDF. The profile of MSWI was dominated by 1,2,3,4,6,7,8HpCDD, OCDD, and 1,2,3,4,6,7,8-HpCDF. The profile of MWI was dominated by 2,3,4,7,8PeCDF, 1,2,3,4,6,7,8-HpCDF, and 1,2,3,7,8-PeCDF. The profile of CK was dominated by 2,3,7,8-TeCDF, 1,2,3,7,8-PeCDF, and 2,3,4,7,8-PeCDF. However, the profile of CR was dominated by $1,2,3,4,6,7,8-\mathrm{HpCDF}, 1,2,3,4,6,7,8-\mathrm{HpCDD}$, and OCDD. 
Fig. 1 also indicates that MSWI and CR were dominated by PCDD, and IWIa, IWIb, CK and MWI were dominated by PCDF. Moreover, the major and minor dominating congener profiles of IWIb were similar to those of IWIa; and MSWI and CR had similar congener profiles.

Table 1. The PCDD/F concentrations in the stack-flue gases of six emission sources.

\begin{tabular}{|c|c|c|c|c|c|c|c|c|c|c|c|c|}
\hline \multirow{2}{*}{$\begin{array}{l}\mathrm{PCDD} / \mathrm{PCDFs} \\
\left(\mathrm{ng} / \mathrm{Nm}^{3}\right)\end{array}$} & \multicolumn{2}{|c|}{$\begin{array}{l}\text { IWI a } \\
(n=3)\end{array}$} & \multicolumn{2}{|c|}{$\begin{array}{l}\text { IWI b } \\
(n=3)\end{array}$} & \multicolumn{2}{|c|}{$\begin{array}{l}\text { MSWI } \\
(n=3)\end{array}$} & \multicolumn{2}{|c|}{$\begin{array}{l}\text { MWI } \\
(n=3)\end{array}$} & \multicolumn{2}{|c|}{$\begin{array}{c}\mathrm{CK} \\
(\mathrm{n}=3)\end{array}$} & \multicolumn{2}{|c|}{$\begin{array}{c}\text { CR } \\
(\mathrm{n}=3)\end{array}$} \\
\hline & mean & RSD(\%) & mean & $\operatorname{RSD}(\%)$ & mean & $\operatorname{RSD}(\%)$ & mean & $\mathrm{RSD}(\%)$ & mean & $\operatorname{RSD}(\%)$ & mean & $\operatorname{RSD}(\%)$ \\
\hline $2,3,7,8-\mathrm{TeCDD}$ & 0.001 & 12.7 & 0.006 & 13.8 & 0.29 & 36.0 & 0.016 & 88.6 & 0.018 & 139 & 0.319 & 27.0 \\
\hline $1,2,3,7,8-\mathrm{PeCDD}$ & 0.003 & 17.9 & 0.022 & 6.67 & 1.18 & 37.7 & 0.042 & 92.8 & 0.01 & 105 & 1.15 & 23.7 \\
\hline $1,2,3,4,7,8-\mathrm{HxCDD}$ & 0.005 & 32.6 & 0.013 & 12.5 & 0.823 & 43.9 & 0.02 & 93.3 & 0.003 & 57.1 & 0.834 & 23.3 \\
\hline $1,2,3,6,7,8-\mathrm{HxCDD}$ & 0.009 & 26.8 & 0.022 & 11.5 & 1.41 & 43.8 & 0.044 & 92.3 & 0.004 & 50.6 & 1.39 & 16.7 \\
\hline 1,2,3,7,8,9-HxCDD & 0.006 & 27.3 & 0.018 & 4.84 & 0.987 & 43.9 & 0.042 & 91.5 & 0.003 & 52.8 & 1.40 & 17.9 \\
\hline $1,2,3,4,6,7,8-\mathrm{HpCDD}$ & 0.056 & 38.4 & 0.117 & 12.0 & 5.19 & 51.1 & 0.089 & 74.8 & 0.014 & 39.6 & 4.55 & 28.1 \\
\hline OCDD & 0.105 & 42.2 & 0.213 & 36.0 & 4.38 & 55.8 & 0.076 & 43.0 & 0.022 & 24.3 & 4.05 & 47.1 \\
\hline $2,3,7,8-\mathrm{TeCDF}$ & 0.009 & 14.7 & 0.064 & 9.53 & 1.54 & 33.5 & 0.095 & 81.3 & 0.114 & 119 & 1.66 & 33.7 \\
\hline $1,2,3,7,8-\mathrm{PeCDF}$ & 0.013 & 18.0 & 0.096 & 8.06 & 1.64 & 43.6 & 0.11 & 86.5 & 0.04 & 95.3 & 1.25 & 32.5 \\
\hline 2,3,4,7,8-PeCDF & 0.023 & 23.9 & 0.127 & 18.4 & 2.49 & 44.7 & 0.152 & 88.5 & 0.039 & 78.9 & 1.82 & 23.3 \\
\hline $1,2,3,4,7,8-\mathrm{HxCDF}$ & 0.03 & 41.5 & 0.116 & 14.1 & 1.69 & 46.4 & 0.096 & 88.0 & 0.013 & 40.6 & 1.65 & 37.5 \\
\hline $1,2,3,6,7,8-\mathrm{HxCDF}$ & 0.032 & 39.2 & 0.122 & 12.4 & 1.82 & 48.6 & 0.105 & 90.5 & 0.018 & 42.9 & 1.76 & 34.9 \\
\hline $2,3,4,6,7,8-\mathrm{HxCDF}$ & 0.004 & 116.4 & 0.009 & 11.7 & 0.086 & 50.2 & 0.004 & 76.5 & 0.001 & 173 & 0.061 & 30.0 \\
\hline $1,2,3,7,8,9-\mathrm{HxCDF}$ & 0.036 & 38.5 & 0.107 & 15.4 & 2.17 & 50.5 & 0.067 & 86.1 & 0.016 & 42.9 & 1.60 & 32.9 \\
\hline $1,2,3,4,6,7,8-\mathrm{HpCDF}$ & 0.149 & 58.1 & 0.232 & 16.0 & 3.43 & 55.0 & 0.125 & 71.9 & 0.022 & 32.0 & 5.02 & 46.3 \\
\hline $1,2,3,4,7,8,9-\mathrm{HpCDF}$ & 0.02 & 56.8 & 0.035 & 18.3 & 0.397 & 57.7 & 0.015 & 64.0 & 0.004 & 40.8 & 0.357 & 40.6 \\
\hline OCDF & 0.102 & 63.0 & 0.077 & 37.2 & 0.567 & 58.3 & 0.044 & 30.6 & 0.009 & 15.2 & 0.964 & 51.3 \\
\hline PCDDs & 0.185 & 34.4 & 0.412 & 23.5 & 14.3 & 49 & 0.329 & 75.4 & 0.074 & 69.8 & 13.7 & 29.2 \\
\hline PCDFs & 0.419 & 49.3 & 0.985 & 15.7 & 15.8 & 47.7 & 0.813 & 80.8 & 0.276 & 85.3 & 16.1 & 36.1 \\
\hline $\mathrm{PCDD} /$ Fs ratio & 0.464 & 20.3 & 0.415 & 7.92 & 0.903 & 9.43 & 0.423 & 12.4 & 0.292 & 14.3 & 0.869 & 11.6 \\
\hline Total PCDD/Fs & 0.604 & 43.8 & 1.397 & 17.9 & 30.1 & 47.9 & 1.14 & 79.2 & 0.35 & 82 & 29.8 & 32.8 \\
\hline PCDDs ng I-TEQ $/ \mathrm{Nm}^{3}$ & 0.005 & 21.6 & 0.024 & 8.5 & 1.26 & 39.3 & 0.049 & 90.7 & 0.024 & 128 & 1.30 & 22.9 \\
\hline PCDFs ng I-TEQ/ $\mathrm{Nm}^{3}$ & 0.025 & 30.7 & 0.113 & 15.8 & 2.10 & 44.8 & 0.12 & 87.6 & 0.038 & 87.1 & 1.70 & 28.6 \\
\hline PCDD/Fs TEQ ratio & 0.21 & 10.3 & 0.217 & 10.3 & 0.616 & 9.47 & 0.395 & 7.42 & 0.495 & 53.3 & 0.78 & 9.18 \\
\hline Total ng I-TEQ/ $/ \mathrm{Nm}^{3}$ & 0.030 & 29.1 & 0.137 & 14.3 & 3.35 & 42.7 & 0.168 & 88.5 & 0.062 & 103 & 3.00 & 25.8 \\
\hline
\end{tabular}

\section{Factor Analysis}

To understand the underlying factors affecting the formation of $\mathrm{PCDD} / \mathrm{Fs}$ in incinerators, factor analysis (FA) was employed. In this work, factors were extracted using principal component analysis (PCA), which involves varimax orthogonal rotation to determine the eigen values of variance matrix of variables (Wilkinson et al., 1996; Johnson and Wichern, 2002). Usually, those factors with eigen values exceeding unity were chosen. In Table 2, two factors, Factor1 and Factor2, are shown corresponding to the two leading eigenvalues of 6.251 and 5.506, 
respectively. Factor 1 explains $39.9 \%$ of all variance, and Factor2 explains $29.0 \%$ of all variance; altogether representing $68.9 \%$ of the total variance. Factorl was strongly related $(>0.7)$ to: 1,2,3,7,8-PeCDD, OCDD; 2,3,4,7,8-PeCDF; 1,2,3,4,6,7,8-HpCDF; 1,2,3,4,7,8,9-HpCDF; and OCDF. Factor2 was strongly related ( $>0.7)$ to: 1,2,3,4,7,8-HxCDD; 1,2,3,6,7,8-HxCDD; 1,2,3,7,8,9-HxCDD; and 1,2,3,4,6,7,8-HpCDD.

Also, Fig. 1 shows that Factor1 explains the major congeners of IWIa, IWIb, and MWI; while both Factor1 and Factor2 explain the major congeners of MSWI, CK, and CR. Chlorinecontaining wastes and precursors are known to be responsible for the formation of $\mathrm{PCDD} / \mathrm{Fs}$ (Dickson et al., 1989; Milligan and Altwicker, 1993); therefore, Factor1 and Factor2 may likely represent these two factors - chlorine-containing wastes and precursors; the latter is associated with the products of incomplete combustion. Notably, formation of PCDD/Fs in relatively low temperatures $\left(250-350{ }^{\circ} \mathrm{C}\right)$ in dust-control device is also one important mechanism (Dickson et al., 1992; Luijk et al., 1994).
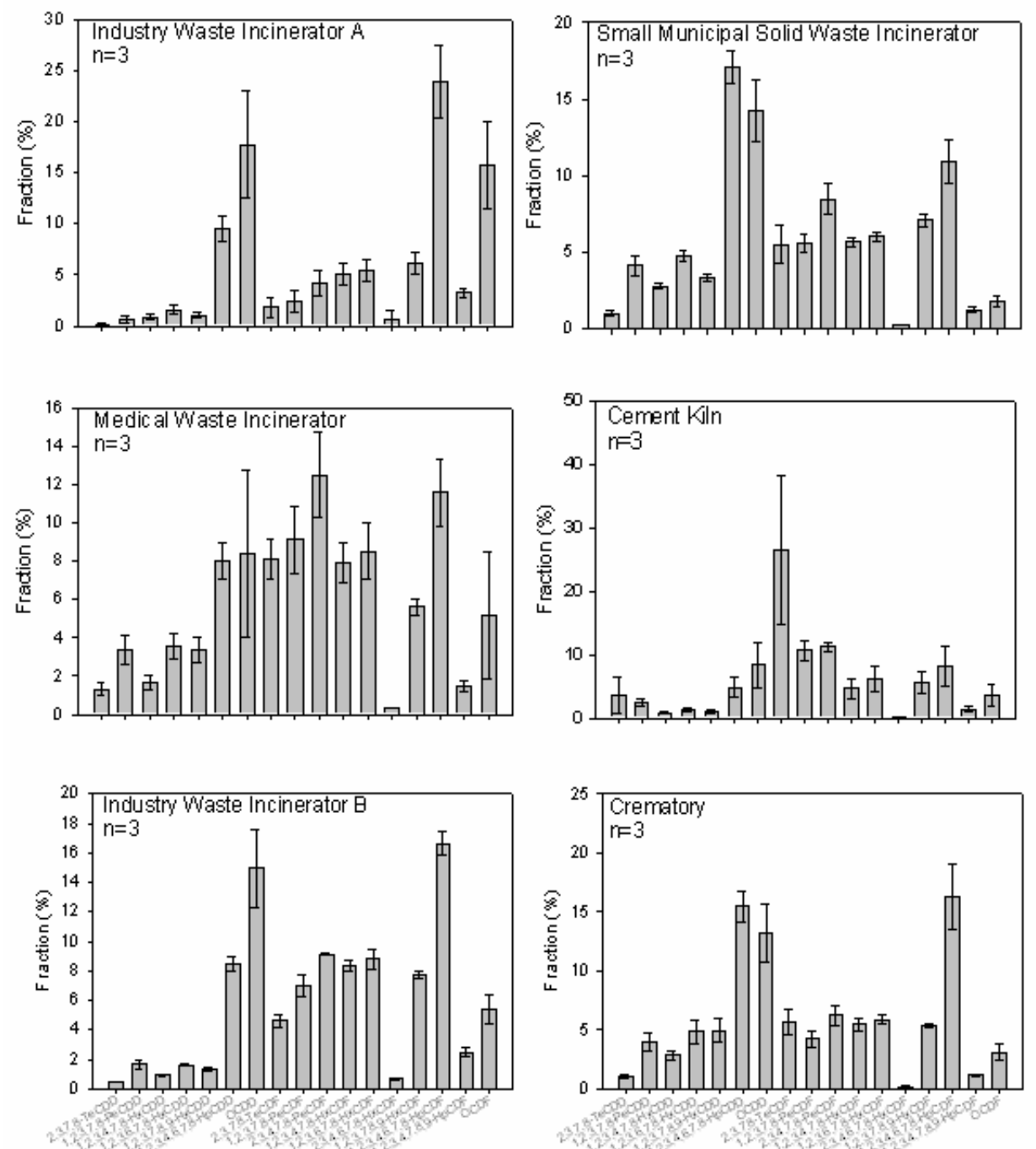

Fig. 1. Congener profiles of seventeen 2,3,7,8 -PCDD/Fs of various emission sources. 
Fig. 2 shows the component plot, with Factor 1 as the horizontal axis and Factor2 as the vertical axis. In the plot, the closeness of the emission sources to each other implies the similarity in their congener profiles. The plot shows that CR and MSWI have similar fingerprints; similarly for IWIb and MWI3.

Table 2. Factor analysis of PCDD/Fs in six stack-flue gases.

\begin{tabular}{ccc}
\hline PCDD/Fs & Factor1 & Factor2 \\
\hline $2,3,7,8-\mathrm{TeCDD}$ & .608 & -.584 \\
$1,2,3,7,8-\mathrm{PeCDD}$ & $\mathbf{. 8 7 2}$ & .446 \\
$1,2,3,4,7,8-\mathrm{HxCDD}$ & .519 & $\mathbf{8 4 5}$ \\
$1,2,3,6,7,8-\mathrm{HxCDD}$ & .539 & $\mathbf{. 8 2 5}$ \\
$1,2,3,7,8,9-\mathrm{HxCDD}$ & .560 & $\mathbf{. 7 4 8}$ \\
$1,2,3,4,6,7,8-\mathrm{HpCDD}$ & .086 & $\mathbf{. 9 5 2}$ \\
OCDD & -.727 & .353 \\
$2,3,7,8-\mathrm{TeCDF}$ & .556 & $\mathbf{- . 7 0 8}$ \\
$1,2,3,7,8-\mathrm{PeCDF}$ & .698 & -.660 \\
$2,3,4,7,8-\mathrm{PeCDF}$ & $\mathbf{. 7 0 0}$ & -.440 \\
$1,2,3,4,7,8-\mathrm{HxCDF}$ & .028 & .041 \\
$1,2,3,6,7,8-\mathrm{HxCDF}$ & .114 & -.101 \\
$2,3,4,6,7,8-\mathrm{HxCDF}$ & -.555 & -.057 \\
$1,2,3,7,8,9-\mathrm{HxCDF}$ & -.224 & .181 \\
$1,2,3,4,6,7,8-\mathrm{HpCDF}$ & $\mathbf{- . 8 6 3}$ & .276 \\
$1,2,3,4,7,8,9-\mathrm{HpCDF}$ & $\mathbf{- . 9 5 9}$ & -.149 \\
OCDF & $\mathbf{- . 8 7 9}$ & -.131 \\
Eigen value & & \\
Percentage of total variance & 6.251 & 5.506 \\
\hline
\end{tabular}

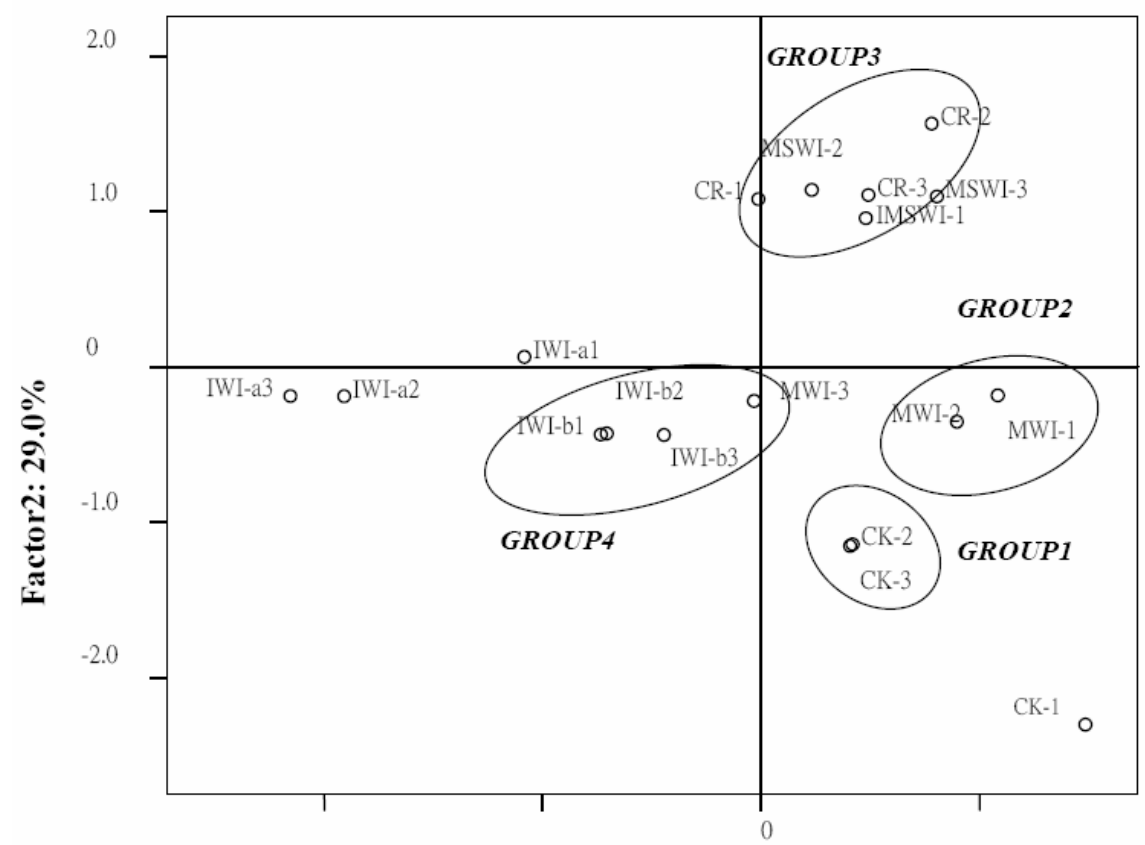

Factor 1: $39.9 \%$

Fig. 2. Component plot from factor analysis. 


\section{Cluster Analysis}

Cluster analysis, using nearest-neighbour method, was employed to divide the congener profiles from different stack-flue gases into several groups (Johnson and Wichern, 2002). The dendrogram in Fig. 3 from cluster analysis shows that if a vertical line is cut at a rescaled distance of four, then the PCDD/F congener profiles fall into four groups, namely: GROUP1, GROUP2, GROUP3, and GROUP4. GROUP1 comprises CK2 and CK3, and GROUP2 comprises MWI1 and MWI2. GROUP 3 comprises MSWI (MSWI1-MSWI3) and CR (CR1CR3) which is consistent with the results of similar fingerprints in these two processes discussed earlier. GROUP4 is comprised of IWIb (IWIb1-IWIb3) and MWI3. IWIa (IWIa1-IWIa3) and CK1 do not belong to any group. Generally, cluster analysis results (Fig. 3) agree fairly well with factor analysis results shown in Fig. 2.

\section{Indicators of PCDD/FS}

Table 3 shows, based on the results of indicatory PCDD/F analysis, that IWIa, IWIb, MSWI, MWI, and CR have similar indicatory PCDD/Fs, which are OCDD, 1,2,3,4,6,7,8-HpCDF, 2,3,4,7,8-PeCDF, and 1,2,3,4,6,7,8-HpCDD. However, $\mathrm{CK}$ has quite different indicatory $\mathrm{PCDD} /$ Fs from the other five incinerator types. This may be due to the fact that the feedstock components of CK contain fewer organic compounds than the other incinerators do.

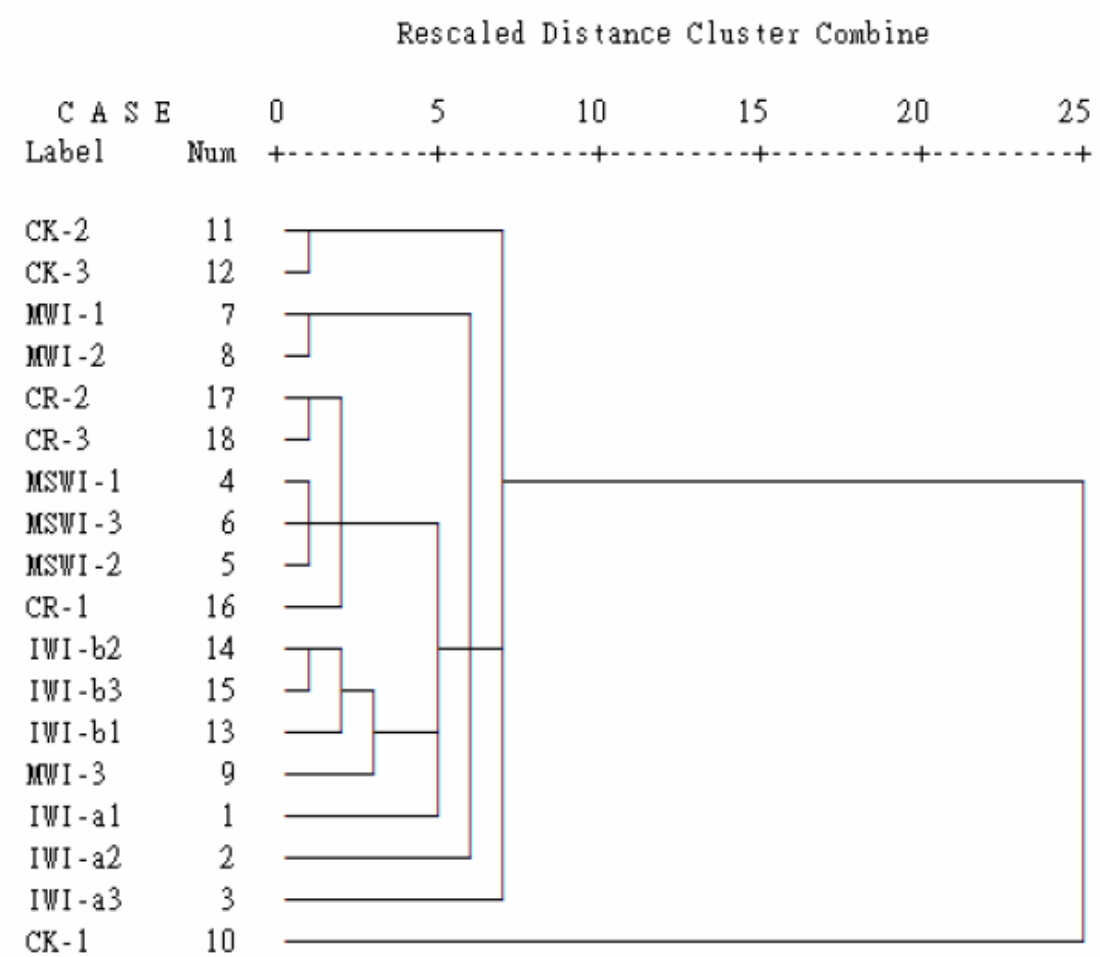

Fig. 3. Dendrogram from cluster analysis. 
Table 3. The highest three indicatory $\mathrm{PCDD} / \mathrm{Fs}$ of various $\mathrm{PCDD} / \mathrm{F}$ emission sources.

\begin{tabular}{ll}
\hline PCDD/F emission sources & Indicatory PCDD/Fs (ratio) \\
\hline IWIa - Industry Waste Incinerator & $1,2,3,4,6,7,8-\mathrm{HpCDF}(0.149)$ \\
& OCDD $(0.105)$ \\
IWIb - Industry Waste Incinerator & OCDF $(0.102)$ \\
& $1,2,3,4,6,7,8-\mathrm{HpCDF}(0.232)$ \\
& OCDD $(0.213)$ \\
MSWI - Small Municipal Solid Waste & $2,3,4,7,8-\mathrm{PeCDF}(0.127)$ \\
Incinerator & $1,2,3,4,6,7,8-\mathrm{HpCDD}(5.193)$ \\
& OCDD $(4.38)$ \\
MWI - Medical Waste Incinerator & $1,2,3,4,6,7,8-\mathrm{HpCDF}(3.433)$ \\
& $2,3,4,7,8-\mathrm{PeCDF}(0.152)$ \\
& $1,2,3,4,6,7,8-\mathrm{HpCDF}(0.125)$ \\
CK - Cement Kiln & $1,2,3,7,8-\mathrm{PeCDF}(0.110)$ \\
& $2,3,7,8-\mathrm{TeCDF}(0.114)$ \\
& $1,2,3,7,8-\mathrm{PeCDF}(0.04)$ \\
$\mathrm{CR}$ - Crematory & $2,3,4,7,8-\mathrm{PeCDF}(0.0385)$ \\
& $1,2,3,4,6,7,8-\mathrm{HpCDF}(5.020)$ \\
& $1,2,3,4,6,7,8-\mathrm{HpCDD}(4.547)$ \\
\hline
\end{tabular}

Table 4. PCDD/F emission factors of various emission sources.

\begin{tabular}{|c|c|c|}
\hline Stationary Source & $\begin{array}{c}\text { Emission factor } \\
(\mu \mathrm{g} \text { I-TEQ/ton-feedstock })\end{array}$ & Reference \\
\hline IWIs with baghouse & $0.059 \pm 31.3$ & This study \\
\hline IWIs with cyclone and ESP & $0.368 \pm 14.3$ & This study \\
\hline $\begin{array}{l}\text { MSWIs with semi dry washing } \\
\text { tower and baghouse }\end{array}$ & $18.7 \pm 43.2$ & This study \\
\hline $\begin{array}{c}\text { MWIs with Venturi scrubber and } \\
\text { quench tower }\end{array}$ & $3.70 \pm 88.7$ & This study \\
\hline CK with ESP & $0.0433 \pm 103$ & This study \\
\hline $\begin{array}{c}\text { CR without pollution control } \\
\text { equipment }\end{array}$ & $41.1 \pm 27.6^{*}$ & This study \\
\hline Secondary ALS & $50.1 \pm 62.5$ & (Chen et al., 2004) \\
\hline Secondary ALS & $0.63-200$ & (Lee et al., 2005) \\
\hline Sinter plants with SCR & 0.970 & (Wang et al., 2003b) \\
\hline Sinter plants without SCR & 3.13 & (Wang et al., 2003b) \\
\hline EAFs & $0.52-3.2$ & (Lee et al., 2005) \\
\hline CR with bag filter & $6.11 *$ & (Wang et al., 2003a) \\
\hline CR without bag filter & $13.6^{*}$ & (Wang et al., 2003a) \\
\hline
\end{tabular}

* Unit: $\mu \mathrm{g}$ I-TEQ/body

\section{Emission Factors of PCDD/FS}

Table 4 shows that the emission factors of PCDD/Fs herein were from 0.0433 (CK) to $18.7 \mu \mathrm{g}$ I-TEQ/ton-feedstock (MSWI), whereas previous studies yielded 0.52 to $200 \mu \mathrm{g}$ I-TEQ/ tonfeedstock (Wang et al., 2003a and 2003b). The PCDD/F emission factors of CR were $41.1 \mu \mathrm{g} \mathrm{I-}$ TEQ/ body herein, a value which is around three times greater than the value reported by Wang et al. (2003a). The PCDD/F emission factors of MSWI and MWI ranked second and third herein. 
It is known that precursors are responsible for the formation of PCDD/Fs. Therefore, the control of feedstock components and the complete combustion of wastes are important in reducing the emission of PCDD/Fs from the stack-flue gas.

\section{CONCLUSIONS}

(1) The total PCDD/F I-TEQ concentrations in the stack gases of IWIa, IWIb, MSWI, MWI, cement kiln (CK) and crematory (CR) were 0.030, 0.137, 3.352, 0.168, 0.062, and 3.003 ng I-TEQ/Nm3, respectively. The total PCDD/F I-TEQ followed the order MSWI $>$ CR $>$ MWI $>$ IWIb $>$ CK $>$ IWIa.

(2) The factor analysis results showed that CR and MSWI have similar fingerprints; similarly between IWIb and MWI3. The cluster analysis showed that if a vertical line is cut at a rescaled distance of four, then the PCDD/F congener profiles fall into four groups. These two analyses generally yielded consistent results.

(3) The indicators of PCDD/Fs of IWIa, IWIb, MSWI, MWI, and CR were very similar. They were OCDD, 1,2,3,4,6,7,8-HpCDF, 2,3,4,7,8-PeCDF, and 1,2,3,4,6,7,8-HpCDD, which were quite different from those of CK.

(4) The emission factors of PCDD/Fs herein were between 0.0433 (CK) and 18.7 (MSWI) $\mu \mathrm{g}$ I-TEQ/ton-feedstock.

Since precursors are responsible for the formation of PCDD/Fs, additional studies should be conducted to provide further understanding on their formation mechanisms during combustionrelated processes.

\section{ACKNOWLEDGEMENTS}

The authors would like to thank Professor Lin-Chi Wang for his insightful discussion on this article and Mr. Chun-Chi Chen for his help in the sampling work.

\section{REFERENCES}

Chen, S.-J., Lee, W.-S., Guo-Ping, C.-C., Wang, L.-C., Lee, W.-J., Kao, J.-H. and Hu, M.T.M.-T., (2004). Characterizing polychlorinated dibenzo-p-dioxins and dibenzofurans in the surrounding environment and workplace of a secondary aluminum smelter. Atmospheric Environment. 38(22): 3729-3732.

Dickson, L.-C., Lenoir, D. and Hutzinger, O. (1989). Surface-catalyzed formation of chlorinated dibenzodioxins and dibenzofurans during incineration. Chemosphere. 19: 277-282. 
Dickson, L.-C., Lenoir, D. and Hutzinger, O. (1992). Quantitative comparison of de Nova and formation of polychlorinated dibenzo-p-dioxins under simulated municipal solid waste incinerator post-combustion conditions. Environmental Science and Technology. 26: 18221828.

Johnson, R.-A. and Wichern, D.-W. (2002). Applied Multivariate Statistical Analysis. 5th ed., Prentice-Hall, Inc., New Jersey, USA.

Lee, W.-S., Chang-Chien, G.-P., Chen, S.-J., Wang, L.-C., Lee, W.-J. and Wang, Y.-H., (2004). Removal of Polychlorinated Dibenzo-p-dioxins and Dibenzofurans in Flue Gases by Venturi Scrubber and Bag Filter. Aerosol and Air Quality. 4(1): 27-37.

Lee, W.-S., Guo-Ping, C.-C. and Wang, L.-C., (2005). Emissions of Polychlorinated Dibenzo-pDioxins and Dibenzofurans from Stack Gases of Electric Arc Furnaces and Secondary Aluminum Smelters. Journal of the Air \& Waste Management Association. 55: 219-226.

Luijk, R., Akkerman, D.-M., Slot, P., Olie, K. and Kapteijn, F. (1994). Mechanism of formation of polychlorinated dibenzo-p-dioxins and dibenzofurans in the catalyzed combustion of carbon. Environmental Science and Technology. 28: 312-321.

Milligan, M.-S., Altwicker, E. (1993). The relationship between de Nova synthesis of polychlorinated dibenzo-p-dioxins and dibenzofurans and low-temperature carbon gasification in fly ash. Environmental Science and Technology. 27: 1595-1601.

Park, S., Kim, S.-J., Kim, K.S., Lee, D.S. and Kim, J.G., (2004). Influence of an Industrial Waste Incinerator as Assessed by the Levels and Congener Patterns of Polychlorinated Dibenzo-pdioxins and Polychlorinated Dibenzofurans. Environ. Sci. Technol. 38: 3820-3826.

Tuppurainen, K., Asikainen, A., Ruokojärvi, P. and Ruuskanen , J., (2003). Perspectives on the Formation of Polychlorinated Dibenzo-p-dioxins and Dibenzofurans during Municipal Solid Waste (MSW) Incineration and Other Combustion Processes. Accounts of Chemical Research. 36 (9).

Wang, L.-C., Lee, W.-J., Lee, W.-S., Chang-Chien, G.-P. and Tsai, P.-J., (2003a). Characterizing the Emissions of Polychlorinated Dibenzo-p-dioxins and Dibenzofurans from Crematories and Their Impacts to the Surrounding Environment. Environ. Sci. Technol. 37(1): 62-67.

Wang, L.-C., Lee, W.-J., Tsai, P.-J., Lee, W.-S. and Chang-Chien, G.-P., (2003b). Emissions of polychlorinated dibenzo-p-dioxins and dibenzofurans from stack-flue gases of sinter plants. Chemosphere. 50(9): 1123-1129.

Wilkinson, L., Blank, G. and Gruber, C. (1996). Desktop Data Analysis with SYSTAT. PrenticeHall, Inc., Upper Saddle River, NJ, USA.

Received for review, November 25, 2005

Accepted, May 12, 2006 